\title{
Evaluation of biochemical indices for assessing growth and condition of the deepwater squid Moroteuthis ingens
}

\author{
Jayson M. Semmens ${ }^{1, *}$, George D. Jackson ${ }^{2}$ \\ ${ }^{1}$ Marine Research Laboratories, Tasmanian Aquaculture and Fisheries Institute, University of Tasmania, Private Bag 49, \\ Hobart, Tasmania 7001, Australia \\ ${ }^{2}$ Institute of Antarctic and Southern Ocean Studies, University of Tasmania, Private Bag 77, Hobart, Tasmania 7001, Australia
}

\begin{abstract}
This study investigated whether biochemical indices (RNA, DNA and protein concentrations and RNA:protein and RNA:DNA ratios) of the mantle muscle and digestive gland were related to growth and condition in wild-caught squid Moroteuthis ingens. The influence of size, sex and reproductive maturity on these relationships was also examined. Levels of RNA, DNA and RNA:protein ratios in the digestive gland were much higher than those in muscle, perhaps due to the high metabolic activity of the gland. The digestive gland of females, however, showed no correlation for any of the indices. There was a general trend of smaller immature males and females having higher levels of biochemical indices compared to larger mature individuals, which was most probably a trade-off between somatic and reproductive growth. RNA concentration and RNA:protein ratio demonstrated the greatest number of correlations with measures of growth and condition, suggesting that they are the most appropriate biochemical indices for $M$. ingens. There was weak support for using RNA:protein and RNA:DNA ratios to assess the condition of $M$. ingens. Despite this, there was little support for the biochemical indices being directly related to growth rates. Faster growing females had lower levels of RNA, DNA, protein and RNA:protein ratios than slower growing individuals, negating the rationale that these indices are a measure of instantaneous growth. These results, however, may represent a lag between whole body growth and RNA levels. Alternatively, biochemical indices may simply not be suitable for field studies of cephalopods.
\end{abstract}

KEY WORDS: Squid · Biochemical indices · Nucleic acid · Growth • Condition · Muscle tissue • Digestive gland $\cdot$ Moroteuthis ingens

\section{INTRODUCTION}

Moroteuthis ingens is an ecologically important squid inhabiting the subantarctic Southern Ocean (Jackson et al. 1998, Phillips et al. 2001). Growth and condition of this squid are of particular interest because of the extreme tissue breakdown associated with maturation and a terminal-spawning strategy. $M$. ingens is a sexually dimorphic species, with females attaining sizes up to 5 times that of males. Ovaries of females alone often exceed the total weight of males and grow to eventually fill the mantle cavity, resulting in inhibition of feeding (Jackson \& Mladenov 1994). Simultaneously with the cessation of feeding, there is an extreme breakdown of mantle muscle tissue of females, ensuring a virtual loss of muscle and leaving a collagen matrix (Jackson \& Mladenov 1994). Males also demonstrate some muscle breakdown.

Nucleic acid indices, which are generally expressed as the concentration of RNA in fresh tissue or as a ratio of RNA against either DNA or protein, have been shown to be useful indicators of individual growth rate and condition (or health) in a variety of 
fish species (see reviews by Ferron \& Leggett 1994, Suthers 1998). The quantity of RNA in tissue varies directly with the rate of protein synthesis (Houlihan 1991, Ferron \& Leggett 1994, Rooker \& Holt 1996, Suthers 1998) and, as such, should be indicative of specific growth rate of an individual at the point of capture (Houlihan et al. 1990). Additionally, condition can be assessed using nucleic acid indices, since the amount of food eaten by an individual affects the concentration of ribosomes in its somatic tissue and hence its capacity for protein synthesis (Houlihan et al. 1990, Houlihan 1991).

Examining growth and condition at the individual level is particularly important in cephalopods, as they are characterised by highly variable growth rates (Jackson 1994) that subsequently produce large differences in longevity (Forsythe \& Hanlon 1988), size-atage (Semmens \& Moltschaniwskyj 2000) and size- and age-at-maturity (Forsythe et al. 2001) at the population level. However, the use of nucleic acid indices as a biochemical measure of growth and condition is still relatively new to the field of cephalopod biology.

Despite this, these nucleic acid indices, along with protein concentration, have been related to growth rate in several cephalopod species in the laboratory (e.g. Sepia officinalis: Clarke et al. 1989, Castro \& Lee 1994, Koueta et al. 2000; Octopus vulgaris: Houlihan et al. 1990, Pierce et al. 1999; Eledone cirrhosa: Houlihan et al. 1998). Additionally, these indices have also been related to the condition of laboratory individuals in a few species (e.g. E. cirrhosa: Houlihan et al. 1998; S. officinalis: Castro \& Lee 1994, Koueta et al. 2000; Loligo forbesi: Pierce et al. 1999; Sepioteuthis lessoniana: Moltschaniwskyj \& Jackson 2000). The only field study to examine relationships between growth rate and these biochemical indices demonstrated no correlation between growth rate and RNA:protein ratio in Sepioteuthis australis (Ho et al. 2004); thus, applicability of these biochemical indices for determining nutritional status and growth rate of wild-caught cephalopods is still relatively untested.

The aims of the present study were to determine if biochemical indices (RNA, DNA and protein concentration, RNA:protein and RNA:DNA ratios) for both the mantle muscle and the digestive gland were good correlates of growth rate and condition in wildcaught individuals of the onychoteuthid squid Moroteuthis ingens. As such, we tested the hypothesis that these indices are indicative of specific growth rate and condition of an individual at the point of capture. Moreover, we examined the influence of size, sex and reproductive maturity on correlations between the biochemical indices and growth and condition. The relative effectiveness of the various indices for examining wild-caught cephalopods was also compared.

\section{MATERIALS AND METHODS}

Specimen collection. We collected 51 individuals of Moroteuthis ingens in southern, subantarctic New Zealand waters, between 46 and $54^{\circ} \mathrm{S}$ and 166 and $175^{\circ} \mathrm{W}$ during November and December 2000, using the RV 'Tangaroa' equipped with a bottom trawl. Whole squid were sexed and weighed (total weight, TW, g) and dorsal mantle length (ML, mm) was recorded. The digestive gland, mantle muscle and portions of the reproductive system (ovary, oviducts, oviducal glands and nidamental glands from females; testis, penis and spermatophoric complex from males) were also weighed. The digestive gland index (DGI) and gonadosomatic index (GSI) were calculated as:

$$
\begin{aligned}
& \text { DGI }=\frac{\text { digestive gland weight }}{\text { TW }- \text { digestive gland weight }} \times 100 \\
& \text { GSI }=\frac{\text { total reproductive weight }}{\text { TW }- \text { total reproductive weight }} \times 100
\end{aligned}
$$

Total reproductive weight for both males and females was measured as the combined weight of all component parts of the respective reproductive system. Muscle tissue from the anterior region of the mantle and digestive gland tissue were snap-frozen in liquid nitrogen for protein/RNA/DNA analysis. The head of each individual was frozen and stored for later removal of statoliths.

Biochemical analysis. Ultra-frozen digestive gland and mantle muscle were weighed before being homogenised in perchloric acid. Concentrations of each compositional element were quantified colorimetrically and measured using a spectrophotometer. Samples were run in duplicate for each assay and repeated if a difference of $20 \%$ between duplicates was recorded. Protein concentration was determined using a modification of the method of Lowry et al. (1951). RNA and DNA concentrations were determined using the dual absorbance technique and measured at 232 and $260 \mathrm{~nm}$ (Ashford \& Pain 1986), with standards run to validate the technique. Fewer digestive gland samples were examined because the high lipid content of the gland (Phillips et al. 2001, 2002, 2003) makes solutions difficult to centrifuge. The concentrations of protein, RNA and DNA were calculated and expressed as $\mathrm{\mu g} \mathrm{mg}^{-1}$ of mantle muscle and digestive gland (wet weight); $\mu \mathrm{g}$ RNA $\mathrm{mg}^{-1}$ protein (RNA:protein ratio) and RNA:DNA ratio were also calculated.

Age and growth. Statoliths were removed from 43 of the 51 squid and prepared after Jackson (1997), with the modification of placing a coverslip over the crystalbond-mounted statolith to enhance increment resolution. Increments were viewed on a monitor using a 
microscope at $400 \times$ magnification via a digital camera attached to a computer. Total increment counts were taken as the age (in days) and were calculated by averaging 2 replicate counts that differed by less than $10 \%$ of the mean. Although statolith increment periodicity has not been validated in this species, the increments are considered to be putative daily increments. Some support for the daily periodicity in Moroteuthis ingens statolith increments has come from matching hatch dates back-calculated from statolith ages (Jackson 1997) to known spawning periods (Jackson 2001).

Growth rates were calculated separately for males and females as the instantaneous relative growth rate $(G)$ for both weight and length:

$$
G=100 \times \frac{\ln S_{2}-\ln S_{1}}{t_{2}-t_{1}}
$$

where $S_{1}$ and $S_{2}$ are the initial and final sizes, expressed as TW or ML and $t_{1}$ and $t_{2}$ are the days of measurement, where $t_{2}-t_{1}$ is the age of the individual estimated from statolith increments. As there are no hatchling sizes or weights for Moroteuthis ingens or other onychoteuthid squids available in the literature, $1.3 \mathrm{~mm}$ was used as an estimate of initial size for $M$. ingens. This was based on the size range of hatchlings of another abundant group of oceanic squids, the ommastrephids (Laptikhovsky et al. 1993). Using this value, an initial weight estimate of $0.007748 \mathrm{~g}$ was calculated from the equation: weight $=(0.00053 \mathrm{ML})^{2.42}$ (Laptikhovsky et al. 1993).

Statistical analysis. Power growth functions were fitted for males and females separately to examine the influence of sex on the total weight-at-age (growth) and mantle weight-at-size (condition) relationships. As sex was found to significantly affect these relationships (determined from the plot for total weight-at-age and using ANCOVA comparing slopes for mantle weightat-size), sexes were examined separately. $G$ were compared between males and females using a Student's $t$ test. Growth and condition residuals were calculated for each individual separately for both males and females using Model II geometric mean regressions on log-transformed data and standardised to a mean of 0 , with a standard deviation of 1 , eliminating the effect of body size. Growth residual was calculated as the difference between the observed total weight-at-age and the predicted total weight-at-age. Individuals that had positive residuals were considered to be growing faster (i.e. were heavier for their age) than individuals that had negative residuals. Similarly, condition residuals were calculated using the mantle weight-ML regression. Individuals with positive residuals were considered to be in better condition (i.e. had heavier mantles for their length) than individuals with negative residuals.
Pearson correlation coefficients were used to determine the association between protein and RNA concentration and RNA:protein and RNA:DNA ratios of the mantle muscle and digestive gland with growth and condition residuals, ML, TW, $G_{\mathrm{ML}}, G_{\mathrm{TW}}$, GSI and DGI. Given the problems of inflated Type I error rates when using the same data in a number of statistical tests, probability values were used as a guide. Levels of biochemical indices for both mantle muscle and digestive gland were compared between males and females using Student's $t$-tests.

\section{RESULTS}

\section{Growth}

Individual squid varied considerably in their total weight-at-age (Fig. 1). Females showed the greatest variation, with only $19 \%$ of the variability explained by age (slope $=2.80 \pm 1.23 \mathrm{SE}, \mathrm{r}^{2}=0.19, \mathrm{n}=24$ ) compared to $30 \%$ for males (slope $=4.42 \pm 1.64 \mathrm{SE}, \mathrm{r}^{2}=0.30, \mathrm{n}=$ 19). Generally females were significantly heavier for their age than males, with an approximately 3.7-fold difference between the average weight of males and females. Females also displayed a greater age range than males: females between 141 and $272 \mathrm{~d}$ old, males between 148 and 214 d old. Despite differences in growth curves for males and females, there was no significant difference in the instantaneous $G$ for either TW, with both males and females averaging over $6 \%$ $\mathrm{TW} \mathrm{d}^{-1}$ (males $=6.17 \pm 0.13 \% \mathrm{TW} \mathrm{d}^{-1}$, females $=6.29 \pm$ $0.18 \% \mathrm{TW} \mathrm{d}^{-1} ; t=0.556, \mathrm{df}=40, \mathrm{p}=0.581$ ) or ML, with

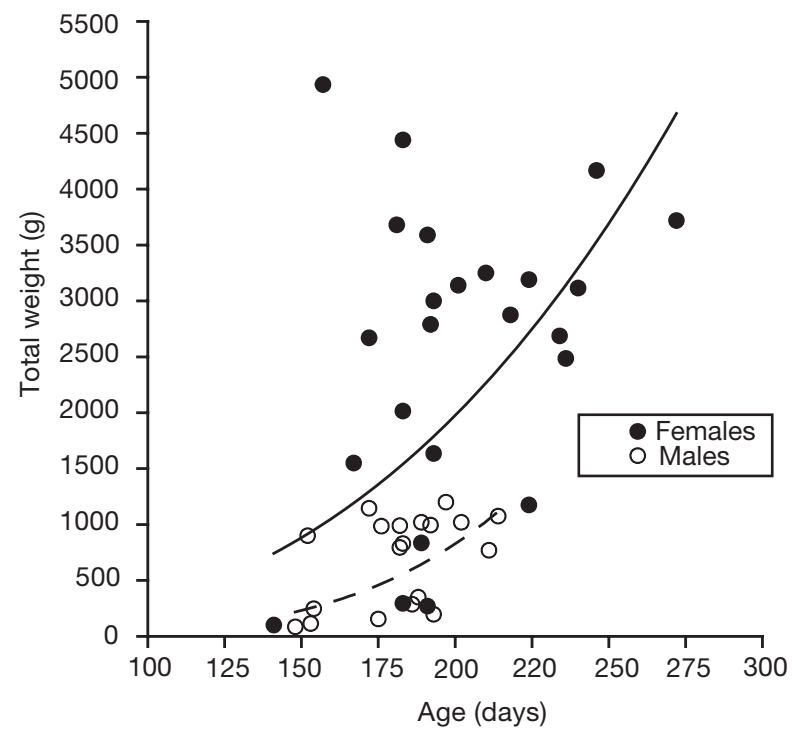

Fig. 1. Moroteuthis ingens. Total weight-at-age relationships for males and females. Power regression lines are given 


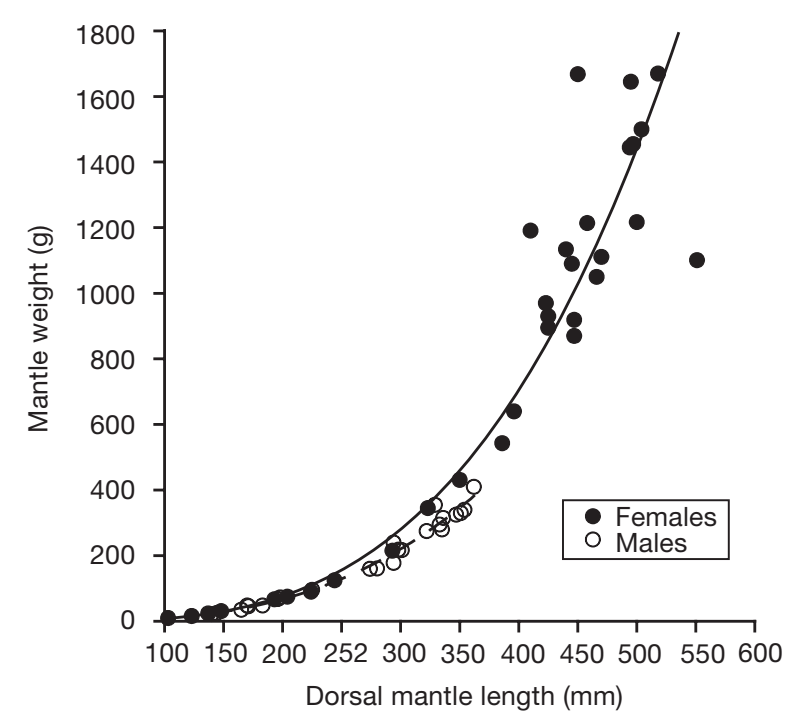

Fig. 2. Moroteuthis ingens. Mantle weight-at-length relationships for males and females. Power regression lines are given

both sexes averaging approximately $2.9 \% \mathrm{ML} \mathrm{d}^{-1}$ $\left(\right.$ males $=2.94 \pm 0.06 \% \mathrm{ML} \mathrm{d}^{-1}$, females $=2.89 \pm 0.08 \%$ $\mathrm{ML} \mathrm{d}^{-1} ; t=-0.517$, df $=40, \mathrm{p}=0.608$ ).

Individual squid varied less in their mantle weight-atlength relationship (condition) than in their total weight-at-age (growth) (Fig. 2). Females exhibited better condition (i.e. heavier mantles for their length) than males at sizes $>300 \mathrm{~mm} \mathrm{ML}$, with the largest male being approximately $360 \mathrm{~mm}$ ML. Females > $400 \mathrm{~mm} \mathrm{ML}$ demonstrated increased variation in their condition; however, $98 \%$ of the overall variability was explained by ML (slope $=3.21 \pm 0.07 \mathrm{SE}, \mathrm{r}^{2}=0.98, \mathrm{n}=32$ ). There was very little variation in the condition of males, with $99 \%$ of variability in mantle weight explained by $\mathrm{ML}$ (slope $=2.92 \pm 0.06 \mathrm{SE}, \mathrm{r}^{2}=0.99, \mathrm{n}=24$ ).

\section{Biochemical analysis}

For both digestive gland and mantle muscle tissue, protein concentrations were significantly higher in males, as was DNA in the digestive glands. There was also a trend of higher RNA:DNA ratios in the muscle of males, but this was not significant. Conversely, the RNA:DNA ratio in the digestive gland was significantly higher for females. The RNA, DNA, and RNA:protein ratio values for digestive glands were consistently higher than those for the muscle tissue for both sexes (Table 1).

\section{Correlations}

Muscle. With the exception of 2 correlations, all were negative (Table 2). There were also dramatically different trends between sexes, with females demonstrating a greater number of correlations. Notably, only females exhibited correlations between measures of growth and condition and protein concentration (Table 2). In general, both males and females had strong negative correlations between biochemical indices and ML, TW and GSI, although only females had correlations between size and protein concentration and RNA:DNA ratio (Table 2). Again, only females displayed negative correlations between the growth residual and biochemical indices (Table 2). Similarly, the only correlation with instantaneous growth rate was for weight and DNA concentration of females (Table 2). Females demonstrated a positive correlation between the RNA: protein ratio and the condition residual, whereas males demonstrated a positive correlation between RNA:DNA ratio and DGI (Table 2).

Table 1. Moroteuthis ingens. Mean $( \pm \mathrm{SE})$ biochemical indices $(\mathrm{n})$ for mantle muscle tissue and digestive gland. Student's $t$-tests were used to compare the levels of the different indices between males and females: $p$-value is considered significant if $p<0.05$; ${ }^{*}$ equal variances not assumed

\begin{tabular}{|c|c|c|c|c|c|c|}
\hline Index & Males & Females & All & $t$ & df & $\mathrm{p}$ \\
\hline \multicolumn{7}{|l|}{ Mantle muscle } \\
\hline RNA & $1.61 \pm 0.18(22)$ & $1.36 \pm 0.18(28)$ & $1.46 \pm 0.13(50)$ & -0.96 & 48 & 0.341 \\
\hline DNA & $0.23 \pm 0.03(22)$ & $0.22 \pm 0.02(29)$ & $0.22 \pm 0.02(51)$ & -0.40 & 49 & 0.694 \\
\hline Protein & $109.12 \pm 5.47(22)$ & $78.50 \pm 6.92(31)$ & $91.21 \pm 5.05$ & -3.25 & 51 & 0.002 \\
\hline RNA:protein & $14.36 \pm 1.54(22)$ & $15.16 \pm 1.07(28)$ & $14.81 \pm 0.89$ & $0.43^{*}$ & 39.1 & 0.672 \\
\hline RNA:DNA & $7.57 \pm 0.82(22)$ & $5.75 \pm 0.49(29)$ & $6.53 \pm 0.46$ & -2.01 & 49 & 0.050 \\
\hline \multicolumn{7}{|c|}{ Digestive gland } \\
\hline RNA & $5.04 \pm 0.55(16)$ & $4.46 \pm 0.32(14)$ & $4.77 \pm 0.33(30)$ & $-0.91^{*}$ & 23.7 & 0.372 \\
\hline DNA & $1.24 \pm 0.23$ & $0.63 \pm 0.05(14)$ & $0.95 \pm 0.13(30)$ & -2.44 & 28 & 0.021 \\
\hline Protein & $101.74 \pm 5.22(16)$ & $80.64 \pm 8.58(13)$ & $92.28 \pm 5.11(29)$ & $-2.10^{*}$ & 20.3 & 0.048 \\
\hline RNA:protein & $52.19 \pm 5.60$ & $66.89 \pm 9.67(13)$ & $58.78 \pm 5.40$ & 1.38 & 27 & 0.180 \\
\hline RNA:DNA & $4.57 \pm 0.37(16)$ & $7.55 \pm 0.64(14)$ & $5.96 \pm 0.44(30)$ & 4.185 & 28 & 0.000 \\
\hline
\end{tabular}


Digestive gland. The digestive glands of males demonstrated similar negative trends to those for muscle; however, there were no correlations with DNA concentration. Interestingly, females did not show correlations with any of the growth and condition parameters (Table 2). Similarly, male digestive gland analysis also revealed no correlations with protein. However, RNA:DNA ratio showed trends more similar to the muscle of females and was correlated with ML, TW and GSI. As was the case for muscle tissue, there were correlations between RNA concentrations and RNA:protein ratio and ML, weight and GSI (Table 2).

\section{DISCUSSION}

\section{Growth and condition}

This study is unique in using biochemical indices to examine growth and condition in wild-caught cephalopods by correlation of indices to growth estimates from statolith aging and morphometric indices of condition. The disadvantage of a field study examining these correlations is the lack of investigator control over numerous biotic and abiotic factors that affect growth rate and condition. However, if these indices are eventually to be used in the field, we need to begin testing their effectiveness in assessing growth and condition in wild-caught cephalopods. If possible, laboratory studies should be done in parallel, but for deep-water squids such as Moroteuthis ingens, which are difficult to maintain in laboratory conditions, we may have to rely solely on field studies to expand our knowledge.

Growth rates of individual Moroteuthis ingens were highly variable, demonstrating plastic growth responses typical of squid (Jackson 1994). However, huge variation exists in weight-at-age for $M$. ingens, with only 19 and $30 \%$ of variation in TW explained by age for females and males respectively using a power growth model $\left(y=a x^{b}\right)$. Despite females being over 3 times heavier for their age, there was no significant difference between males and females in their lifetime instantaneous growth rates. This suggests that females grow much more rapidly than males as juveniles (i.e. $<141 \mathrm{~d}$ old individuals in this study) to achieve their large sub-adult/adult sizes.

There was no dramatic loss in condition (i.e. mantle weight-at-length) in females, even though Moroteuthis ingens is a terminal spawner (Jackson \& Mladenov 1994, Jackson 2001). However, this may be due to the fact that females appear to continually build-up their

Table 2. Moroteuthis ingens. Summary of significant correlations between growth $(G)$ and condition measures and biochemical indices. Correlation significant at ${ }^{*} \mathrm{p}<0.05$ level and ${ }^{* *} \mathrm{p}<0.01$ level. GSI: gonadosomatic index; DGI: digestive gland index

\begin{tabular}{|c|c|c|c|c|c|}
\hline Element & RNA & DNA & Protein & RNA:protein & RNA:DNA \\
\hline \multicolumn{6}{|l|}{ Male muscle } \\
\hline Mantle length & $-0.894^{* *}$ & $-0.771^{* *}$ & & $-0.904^{* *}$ & \\
\hline Total weight & $-0.907^{* *}$ & $-0.766^{* *}$ & & $-0.918^{* *}$ & \\
\hline \multicolumn{6}{|l|}{ Growth residual } \\
\hline \multicolumn{6}{|l|}{$G_{\text {weight }}$} \\
\hline \multirow{2}{*}{\multicolumn{6}{|c|}{$\begin{array}{l}G_{\text {length }} \\
\text { Condition residual }\end{array}$}} \\
\hline \multicolumn{5}{|l|}{ Condition residual } & \\
\hline GSI & $-0.853^{* *}$ & $-0.457^{*}$ & & $-0.910^{* *}$ & $-0.520^{*}$ \\
\hline DGI & & & & & $0.448^{*}$ \\
\hline \multicolumn{6}{|l|}{ Female muscle } \\
\hline Mantle length & $-0.947^{* *}$ & $-0.859^{* *}$ & $-0.815^{* *}$ & $-0.807^{* *}$ & $-0.586^{* *}$ \\
\hline Total weight & $-0.900^{* *}$ & $-0.804^{* *}$ & $-0.884^{* *}$ & $-0.721^{* *}$ & $-0.619^{* *}$ \\
\hline Growth residual & $-0.446^{*}$ & $-0.734^{* *}$ & $-0.439^{*}$ & $-0.437^{*}$ & \\
\hline$G_{\text {weight }}$ & & $-0.509^{*}$ & & & \\
\hline \multicolumn{6}{|l|}{$G_{\text {length }}$} \\
\hline Condition residual & & & & $0.392^{*}$ & \\
\hline GSI & $-0.619^{* *}$ & & $-0.715^{* *}$ & $-0.462^{*}$ & $-0.752^{* *}$ \\
\hline \multicolumn{6}{|l|}{ DGI } \\
\hline \multicolumn{6}{|l|}{ Male digestive gland } \\
\hline Mantle length & $-0.600^{*}$ & & & $-0.610^{*}$ & $-0.688^{* *}$ \\
\hline Total weight & $-0.684^{* *}$ & & & $-0.675^{* *}$ & $-0.632^{* *}$ \\
\hline \multicolumn{6}{|l|}{ Growth residual } \\
\hline \multicolumn{6}{|l|}{$G_{\text {weight }}$} \\
\hline$G_{\text {length }}$ & & & & & \\
\hline Condition residual & & & & & \\
\hline GSI & $-0.700^{* *}$ & & & $-0.800^{* *}$ & $-0.599^{*}$ \\
\hline DGI & & & & & \\
\hline
\end{tabular}


condition in preparation for spawning. Females show a marked decrease in condition once they are fully mature, with further reduction in spent individuals (Jackson \& Mladenov 1994, Jackson 2001, Jackson et al. 2004).

\section{Biochemical analysis}

Despite the fact that females were significantly heavier for their age and therefore grew faster than males, only RNA:DNA ratios in the digestive gland were higher in females. However, this was expected, given no significant difference between instantaneous growth rates for the size range of males and females and the fact that RNA indices are only a measure of recent growth (Ferron \& Leggett 1994).

RNA and DNA concentrations and RNA:protein ratios of the digestive glands were 3 to 4 times higher than those for muscle. A higher rate of protein synthesis is most likely needed in the digestive gland to constantly replace epithelial cells, which are continually sloughed off as part of the functioning of the gland (Semmens 2002).

\section{Correlations}

Digestive glands of females had no correlation with any of the biochemical indices, despite those of males showing similar trends to muscle. Feeding evidently ceases in mature Moroteuthis ingens when the ovary fills the mantle cavity, and constricts the stomach and caecum making feeding impossible (Jackson \& Mladenov 1994). Therefore, lack of correlation with the digestive gland biochemical indices in females may be due to the gland not functioning throughout the entire life cycle.

The tendency for immature Moroteuthis ingens of both sexes to have higher levels of the biochemical indices in the muscle tissue compared to mature individuals has also been demonstrated in other squid species (e.g. Loligo forbesi: Siegert et al. 1994, Pierce et al. 1999; Sepioteuthis australis: Ho et al. 2004). Higher levels of RNA in immature individuals are indicative of increased rates of protein synthesis and hence rapid growth (Pierce et al. 1999). Growth slows with sexual maturity, as it is affected by protein synthesis for gonads (Houlihan et al. 1998). Given that $M$. ingens is a true terminal spawner with breakdown of muscle tissue occurring during maturation and spawning (Jackson \& Mladenov 1994), it would be expected that mature individuals would have a lower rate of protein synthesis and, as a consequence, lower levels of RNA.
Apart from the RNA:DNA ratio in the muscle tissue of males, the biochemical indices were highly correlated with weight and length of both male and female Moroteuthis ingens. This trend between size and RNA indices has also been demonstrated for adult Sepioteuthis australis (Ho et al. 2004), Loligo forbesi (Pierce et al. 1999) and Eledone cirrhosa (Houlihan et al. 1998), and is likely to be the result of trade-offs between somatic and reproductive growth, as the trend mirrors the relationship between the biochemical indices and maturity for all these species.

The fact that male Moroteuthis ingens demonstrated no relationship between size and RNA:DNA ratio for the muscle tissue suggests that this ratio may not be the best index for examining muscle growth in cephalopods. Previously, RNA:DNA ratios have been reported to lose resolution as a predictor when growth rates are extremely variable (Westerman \& Holt 1994), as is the case with $M$. ingens and cephalopods in general.

Only females showed negative correlations between protein levels in the muscle tissue and body weight, length and the growth residual. This may seem an unexpected result, since protein is positively correlated with body weight in captive Eledone cirrhosa (Houlihan et al. 1998). However, protein levels are also correlated with feeding rate in captive Loligo forbesi (Pierce et al. 1999), suggesting that protein concentration is sensitive to recent feeding (Pierce et al. 1999). Male Moroteuthis ingens are likely to feed continuously, as they need to search for mates and do not show the same level of tissue breakdown in females. Conversely, feeding in females declines with maturity, eventually ceasing when their ovaries begin to constrict their digestive system (Jackson \& Mladenov 1994). The negative correlation with size and protein in female $M$. ingens is also likely to represent the larger commitment to reproduction by females, with protein in the mantle acting as the energy reserve (Jackson \& Mladenov 1994, Jackson 2001). This corresponds to a general trend of increased water in tissues, with a concomitant decrease in protein during maturation (Jackson et al. 2004), as is also seen in gonatid squids (Arkhipkin \& Bjorke 1999).

Pierce et al. (1999) found a negative correlation between instantaneous $G$ for weight and protein in captive Octopus vulgaris. Although protein did not correlate with $G$ in Moroteuthis ingens, the growth residual was weakly negatively correlated with protein. In both cases, this suggests that individuals that were growing faster had lower levels of protein in their mantles. This seems counterintuitive, however, as $O$. vulgaris also shows tissue breakdown and death associated with spawning (O'Dor \& Wells 1987). This relationship may be related to terminal spawning and needs further examination. 
The negative correlations between the growth residual and the RNA and RNA:protein ratio of female muscle indicates that females that were considered to be growing faster (i.e. heavier for their age, with positive growth residuals) had lower biochemical indices than individuals that were considered to be growing slower (i.e. smaller for their age, with negative growth residuals). This negates the concept that RNA is a measure of instantaneous $G$ and the positive correlations found between $G$ and RNA indices for larval and juvenile fishes (see reviews by Ferron \& Leggett 1994, Suthers 1998) and cultured or laboratory-maintained cephalopods (Clarke et al. 1989, Houlihan et al. 1990, 1998, Castro \& Lee 1994, Koueta et al. 2000). This result may represent a lag between whole-body measures of growth and biochemical indices, with RNA and RNA:protein ratios lagging behind the faster growth these individuals exhibit. The concept of a lag between the amount of RNA and growth was demonstrated for cephalopods by Houlihan et al. (1990), where RNA:protein ratios did not equate to the rate of protein synthesis after feeding in Octopus vulgaris. This phenomenon has also been observed in fishes (MacMillian \& Houlihan 1988) and mammals (Garlick et al. 1983).

DNA concentration of the muscle of females had a strong negative correlation with the growth residual and a negative correlation with instantaneous $G$ for weight, being the only correlation for this measure of growth. This was also unexpected and may suggest that to obtain a significantly larger size-at-age compared to males, females may employ a different growth strategy to that of males. Muscle growth in cephalopods occurs by a combination of an increase in the number of muscle fibres (hyperplasia), and an increase in the size of the fibres (hypertrophy) throughout their life span (Moltschaniwskyj 1994, Pecl \& Moltschaniwskyj 1997). Hyperplasia results in an increase in DNA, while for hypertrophy there is no change in the amount of DNA (Castro \& Lee 1994). The relative contribution of each process to overall muscle growth changes with whole-animal growth, with the suggestion that rates of hyperplasia decrease in larger individuals (Moltschaniwskyj 1994, Pecl \& Moltschaniwskyj 1997). Faster growing females may be achieving this rate of growth by a greater emphasis on increasing the size of fibres than that of slower growing females and males. This would result in relatively lower levels of DNA in the tissue of these individuals. Again this needs further investigation through laboratory studies.

Unlike the growth residual, the condition residual was only correlated with 1 biochemical index-a weak positive correlation with the RNA:protein ratio of females. This suggests that individuals considered to be in better condition (i.e. heavier for their length, with positive condition residuals) had increased RNA:pro- tein ratios and as such had faster growth than those individuals considered to be in worse condition (i.e. lighter for their length, with negative residuals). The fact that only females $>400 \mathrm{~mm}$ ML demonstrated increasing variation in their condition (Fig. 2) may have resulted in a weak correlation. As such, the RNA:protein ratio may be able to be used to assess the condition of wild-caught Moroteuthis ingens and, potentially, other cephalopods.

Male Moroteuthis ingens demonstrated a weak positive correlation between the RNA:DNA ratios of muscle tissue and DGI. This suggests that the DGI may be an index of recent feeding rate in $M$. ingens, as it is in captive Loligo forbesi (Pierce et al. 1999) and Eledone cirrhosa (Houlihan et al. 1998).

\section{CONCLUSIONS}

This is the first study to compare the relative effectiveness of the various biochemical growth and condition indices in a cephalopod, in compliance with Pierce et al.'s (1999) suggestion that such a comparison might help increase our knowledge of cephalopod growth and maturity in the wild. Our results suggest that RNA concentration and the RNA:protein ratio are the best indices for Moroteuthis ingens, as they both demonstrate the greatest number of correlations with other measures of growth and condition. Pierce et al. (1999) suggest that RNA concentration is likely to be a better index than the RNA:protein ratio, as protein concentration was sensitive to recent feeding events in laboratory-maintained Loligo forbesi. However, this was not apparent in the present study, perhaps because this sensitivity is lost in the highly variable marine environment. Protein concentration is not an appropriate growth index for $M$. ingens; however, it is useful for examining transfer of energy with maturation in a terminal-spawning cephalopod.

Despite the correlations, there was only equivocal support for nucleic acid-based biochemical indices being directly related to growth rates and condition for wild-caught individuals of Moroteuthis ingens. This was also the case for the temperate squid Sepioteuthis australis (Ho et al. 2004). Despite RNA indices being good correlates of growth and condition in the majority of reared or laboratory-maintained cephalopods, these measurements may not be applicable to field studies, since the difference may be due to the level of these indices being closely related to prey availability (Koueta et al. 2000, Moltschaniwskyj \& Jackson 2000) and temperature (Clarke et al. 1989) in laboratory-cultured cephalopods, as is also the case for cultured and laboratory-maintained fishes (see review by Ferron \& Leggett 1994). Despite this, growth rate has been 
related to RNA:DNA ratios in field-caught larval and juvenile fishes (e.g. Hovenkamp 1990, Malloy \& Targett 1994), by including a temperature term determined from laboratory studies. Further studies may be needed to develop this kind of approach for cephalopods, if biochemical indices are going to be of use for assessing growth and condition in wild-caught individuals. However, nucleic acid indices may simply not be suitable for studies of cephalopods because of their characteristic highly variable growth: these indices lose resolution with extremely variable growth (Westerman \& Holt 1994) and are more sensitive to relatively slow growth (Koueta et al. 2000).

Acknowledgements. We thank the staff at NIWA, New Zealand, and the Master and crew of the RV 'Tangaroa', who allowed J.M.S. to join the research cruise and assisted him in collecting squid. Thanks also to J. Harrington and J. Ho and L. Ward from the University of Tasmania (UTas), who assisted with statolith preparation and biochemical analysis respectively. C. Carter (UTas) kindly provided laboratory access and biochemical advice. This work was funded by 2 Australian Research Council Large Grants to G.D.J. (Nos. A19933031 and DPO210370).

\section{LITERATURE CITED}

Arkhipkin AI, Bjorke H (1999) Ontogenetic changes in morphometric and reproductive indices of the squid Gonatus fabricii (Oegopsida, Gonatidae) in the Norwegian Sea. Polar Biol 22:357-365

Ashford AJ, Pain VM (1986) Effect of diabetes on the rates of protein synthesis and degradation of ribosomes in rat muscle and liver in vivo. J Biol Chem 261:4059-4065

Castro BG, Lee PG (1994) The effects of semi-purified diets on growth and condition of Sepia officinalis L. (Mollusca: Cephalopoda). Comp Biochem Physiol A 109:1007-1016

Clarke A, Rodhouse PG, Holmes LJ, Pascoe PL (1989) Growth rate and nucleic acid ratio in cultured cuttlefish Sepia officinalis (Mollusca: Cephalopoda). J Exp Mar Biol Ecol 133:229-240

Forsythe JW, Hanlon RT (1988) Effect of temperature on laboratory growth, reproduction and life span of Octopus bimaculoides. Mar Biol 98:369-379

Forsythe JW, Walsh LS, Turk PE, Lee PG (2001) Impact of temperature on juvenile growth and age at first egglaying of the Pacific reef squid Sepioteuthis lessoniana reared in captivity. Mar Biol 138:103-112

Garlick PJ, Fern M, Preedy VR (1983) The effect of insulin infusion and food intake on muscle protein synthesis in post-absorptive rats. Biochem J 210:669-676

Ho JD, Moltschaniwskyj NA, Carter CG (2004) The effect of variability in growth on somatic condition and reproductive status in southern calamary Sepioteuthis australis. Mar Freshw Res 55:423-428

Houlihan DF (1991) Protein turnover in ectotherms and its relationship to energetics. In: Gilles $\mathrm{R}$ (ed) Advances in comparative and environmental physiology, Vol 7 . Springer-Verlag, Heidelberg, p 1-43

Houlihan DF, McMillan DN, Agnisola C, Genoino IT, Foti L (1990) Protein synthesis and growth in Octopus vulgaris. Mar Biol 106:251-259
Houlihan DF, Kelly K, Boyle PR (1998) Correlates of growth and feeding in laboratory-maintained Eledone cirrhosa (Cephalopods: Octopoda). J Mar Biol Assoc UK 78: 919-932

Hovenkamp F (1990) Growth differences in larval plaice Pleuronectes platessa in the southern Bight of the North Sea as indicated by otolith increments and RNA-DNA ratios. Mar Ecol Prog Ser 58:205-215

Jackson GD (1994) Application and future potential of statolith increment analysis in squids and sepioids. Can J Fish Aquat Sci 51:2612-2625

Jackson GD (1997) Age, growth and maturation of the deepwater squid Moroteuthis ingens (Cephalopoda: Onychoteuthidae). Polar Biol 17:268-274

Jackson GD (2001) Confirmation of winter spawning of Moroteuthis ingens (Cephalopoda: Onychoteuthidae) in the Chatham Rise region of New Zealand. Polar Biol 24: $97-100$

Jackson GD, Mladenov PV (1994) Terminal spawning in the deepwater squid Moroteuthis ingens (Cephalopoda: Onychoteuthidae). J Zool 234:189-201

Jackson GD, McKinnon JF, Lalas C, Ardern R (1998) Food spectrum of the deepwater squid Moroteuthis ingens (Cephalopoda: Onychoteuthidae) in New Zealand waters. Polar Biol 20:56-65

Jackson GD, Semmens JM, Phillips KL, Jackson CH (2004) Reproduction in the deepwater squid Moroteuthis ingens, what does it cost? Mar Biol 145:905-916

Koueta N, Castro BG, Boucaud-Camou E (2000) Biochemical indices for instantaneous growth estimation in young cephalopod Sepia officinalis L. ICES J Mar Sci 57:1-7

Laptikhovsky VV, Arkhipkin AI, Golub AA (1993) Larval age, growth and mortality in the oceanic squid Sthenoteuthis pteropus (Cephalopoda, Ommastrephidae) from the eastern tropical Atlantic. J Plankton Res 15:375-384

Lowry OH, Rosebrough NJ, Farr AL, Randall RJ (1951) Protein measurement with folin phenol reagent. J Biol Chem 193:265-275

Malloy KD, Targett TE (1994) The use of RNA:DNA ratios to predict growth limitation of juvenile summer flounder (Paralichthys dentatus) from Delaware and North Carolina estuaries. Mar Biol 118:367-375

McMillan DN, Houlihan DF (1988) The effects of refeeding on tissue protein synthesis in rainbow trout. Physiol Zool 61: $429-441$

Moltschaniwskyj NA (1994) Muscle tissue growth and muscle fibre dynamics in the tropical loliginid squid Photololigo sp. (Cephalopoda Loliginidae). Can J Fish Aquat Sci 51: 830-835

Moltschaniwskyj NA, Jackson GD (2000) Growth and tissue composition as a function of feeding history in juvenile cephalopods. J Exp Mar Biol Ecol 253:229-241

O'Dor RK, Wells MJ (1987) Energy and nutrient flow. In: Boyle PR (ed) Cephalopod life cycles: comparative reviews, Vol II. Academic Press, London, p 109-125

Pecl GT, Moltschaniwskyj NA (1997) Changes in muscle structure associated with somatic growth in Idiosepius pygmaeus a small tropical cephalopod. J Zool 242: 751-764

Phillips KL, Jackson GD, Nichols PD (2001) Predation on myctophids by the squid Moroteuthis ingens around Macquarie and Heard Islands: stomach contents and fatty acid analyses. Mar Ecol Prog Ser 215:179-189

Phillips KL, Nichols PD, Jackson GD (2002) Lipid and fatty acid composition of the mantle and digestive gland of four Southern Ocean squid species: implications for food-web studies. Antarct Sci 14:212-220 
Phillips KL, Nichols PD, Jackson GD (2003) Dietary variation of the squid Moroteuthis ingens at four sites in the Southern Ocean: stomach contents, lipid and fatty acid profiles. J Mar Biol Assoc UK 83:523-534

Pierce GJ, Key LN, Boyle PR, Siegert KJ, Goncalves JM, Porteiro FM, Martins HR (1999) RNA concentration and the RNA to protein ratio in cephalopod tissues: sources of variation and relationship with growth rate. J Exp Mar Biol Ecol 237:185-201

Rooker JR, Holt GJ (1996) Application of RNA:DNA ratios to evaluate the condition and growth of larval and juvenile red drum (Sciaenops ocellatus). Mar Freshw Res 47: 283-290

Semmens JM (2002) Changes in the digestive gland of the loliginid squid Sepioteuthis lessoniana. J Exp Mar Biol

Editorial responsibility: Otto Kinne (Editor-in-Chief), Oldendorf/Luhe, Germany
Ecol 274:19-39

Semmens JM, Moltschaniwskyj NA (2000) An examination of variable growth in the loliginid squid Sepioteuthis lessoniana: a whole animal and reductionist approach. Mar Ecol Prog Ser 193:135-141

Siegert K, Norman J, Pierce GJ, Boyle PR, Key L (1994) Application of biochemical indices to measure growth rates in cephalopods. Int Counc Explor Sea Comm Meet 1994/K:24

Suthers IM (1998) Bigger? Fatter? Or is faster growth better? Considerations on condition in larval and juvenile coralreef fish. Aust J Ecol 23:265-273

Westerman M, Holt GJ (1994) RNA:DNA ratio during the critical period and early larval growth of the red drum Sciaenops ocellatus. Mar Biol 121:1-9

Submitted: November 3, 2003; Accepted: October 12, 2004 Proofs received from author(s): March 8, 2005 